\title{
THE SOURCES TO THE HISTORY OF FUNCTIONING OF THE UKRAINIAN LIBERATION MOVEMENT IN THE CARPATHIAN REGION OF THE OUN (1945-1954) ${ }^{1}$
}

\section{Ilnytskyi V. I.}

\section{INTRODUCTION}

The sources to the topic are characterized by the origin, storage, representativeness of historical facts, manning methods, degree of disclosure of certain aspects of the problem. The almost ten-year struggle of liberation movement in the Carpathian region of the OUN (Organization of Ukrainian Nationalists) has been reflected in a large number of different sources. We agree with Georgyi Papakin's opinion about the inappropriateness of "applying a scheme which provides a fundamental division into published and unpublished archival) sources [...] It is connected, first of all, with the peculiarities of historical sources of national liberation movement of the mid. XX th century, the necessity of the usage in their study all known classification features (origin, geography, authorship, publicity, circulation, storage, etc.). And just the publicity (the degree of actualization), the storage space does not play a significant role" ${ }^{2}$. In the process of the study of the OUN and URA (Ukrainian Rebel Army) struggle, a large number of sources were identified and divided into several main groups depending on their origin or authorship in the broad sense.

\section{The Documents of the OUN and URA}

The first, main, group is the OUN and URA documents. They are stored in central, sectoral, regional and private archives, museums, some are partially published. During the study, documents were mostly used. Because it was the PCIA-MIA and the PCSS-MSS-KGB that were fighting with the OUN and the URA, a considerable array of trophy - rebel documents were preserved in the Sectoral State Archives of the Security Service of Ukraine (SSA SSU). Most originals of clandestine documents (instructions, orders, reports, training programs for training, propaganda

\footnotetext{
${ }^{1}$ The article was published with the support of the Canadian Institute of Ukrainian Studies (with a grant from the Levko and Marika Babij Memorial Endowment Fund). Стаття побачила світ при підтримці Канадського інституту українських студій (з гранту Меморіяльного фонду ім. Левка і Марійки Бабіїв).

${ }^{2}$ Папакін Г. Українські визвольні змагання 1939-1956: джерельний контент. Вип. 1. Проблеми класифікації й змісту джерел повстанського та радянського походження / [відп. ред. Г. Боряк] / Інститут історії України НАН України. К., 2012. С. 105.
} 
literature) are stored in fund 13 ("The Collection of Printed Editions of the KGB of the USSR") of the State Security Service of Ukraine: case 376 (88 volumes), 398 (42 volumes) and, in part, case 372 (103 volumes). O. Ishchuk notes that the formation and staffing of these cases was carried out in the first half of the 1960s by order of the KGB head of the USSR Vitaliy Nikitchenko by the central office and the KGB in Volyn, Lviv, Ivano-Frankivsk, Rivne, Ternopil, Chernivtsi regions. The main organizing work was carried out by the Deputy Head of the Department of the 4th KGB Department of the USSR, Lieutenant Colonel Mykola Makhov. Sometimes, documents, even in single copies, were removed from the KGB regional offices without making copies. It is important to note that the documents of this fund are not systematized even by territorial and chronological principle. The mentioned cases contain instructions, orders, reports, correspondence, training programs, propaganda literature (brochures, leaflets, newspapers, appeals), and there are many underground reports. Of special importance for the study of propaganda activities is the collection of printed editions of OUN structures. Some of the documents are translated into Russian.

Both originals and translations into Russian are rather important and stored in the 2nd fund (Department of Combating Banditry of the Ministry of Internal Affairs, Office 2-N and 4th Department of the MSS-KGB of the USSR). It should be mentioned the diary notes of Peter Fedun-"Poltava" describing the situation in the Carpathian region in mid $-1949^{3}$ and the characteristics of the Carpathian region, compiled by Vasyl Sidor"Shelest". The rebel documents are also stored in f. 65 SSA SSA.

A large body of underground documentation, mainly for the years 1944 - 1946, concerning the problems of the functioning of the Ukrainian liberation movement in the Carpathian region of the OUN, is stored in the Central State Archives of Higher Authorities and Administration of Ukraine (CSAHA of Ukraine $)^{5}$. First of all, in the materials of the funds: 3833 "Crayovyi Provid" of the Organization of Ukrainian Nationalists in Western Ukraine in 1941-1947"; 3836 "The Union of Western Groups of the Ukrainian Rebel Army URA-Zahid". We should note the input and output documentation of the OUN Drohobych propaganda unit for May 1945 - January 1946, especially the district and supra-district level reports and instructions on the structure of the referral ${ }^{6}$.

${ }^{3}$ ГДА СБУ. Ф. 13. Спр. 398. Т. 13. Арк. 150-153.

${ }^{4}$ ГДА СБУ. Ф. 2-Н. Оп. 59 (1953). Спр. 6. Т. 4. Арк. 152-175; Ф. 13. Спр. 372. Т. 9. Арк. 16-59.

${ }^{5}$ ЦДАВО України. Ф. 3833. Оп. 1. Спр. 226. Арк. 123; Ф. 3836. Оп. 1. Спр. 67. Арк. 12, 34, 43-44, 46, 58, 68, 69, 111, 129, 184-184зв., 189, 196, 243, 259, 306; Спр. 70. Арк. 2; Ф. 3838. Оп. 1. Спр. 4а. Арк. 28, 29, 30-32.

${ }^{6}$ ЦДАВО України. Ф. 3836. Оп. 1. Спр. 67: пропагандистські матеріали референта пропаганди округа "Маківка" - “Тустань" - “Аркадія". 381 арк. 
A large number of underground documents (in originals, and partly in Russian copies) are stored in the Central State Archive of Public Associations of Ukraine (CSAPA of Ukraine). There is no separate fund in which all OUN and URA documents would be collected, but the main file is stored in the fund "The Central Committee of the Communist Party of Ukraine" (F. 1. - Op. 23), which contains mostly propaganda materials in copies. The rest of the materials is scattered in various cases of this and other funds (mostly copies).

OUN and URA documents as evidences are contained in archival criminal cases, in particular in funds 5 and 6 of the Branch State Archives of the Security Service of Ukraine and the regional offices of the Security Service of Ivano-Frankivsk, Transcarpathia, Lviv and Chernivtsi regions.

The part of the underground documents were kept in the state archives of the Transcarpathia, Ivano-Frankivsk, Lviv, Chernivtsi regions, as well as in the funds of regional committees of the Communist Party (Bolsheviks) of Ukraine $(\mathrm{CP}(\mathrm{b}) \mathrm{U})$ of Transcarpathia (f. P-1), IvanoFrankivsk (f. P-1), Lviv (P-5001), Chernivtsi (f. P-1) regions.

It is worth noting a certain feature of the State Archives of Lviv region (SALR), which contains a large array of individual cases of struggle of the authorities with the liberation movement, underground documents, special instructions. Apparently, under the pressure of the public and the reluctance of the archives to execute a criminal order, these documents are preserved. The large P-5001 fund - Drohobych Regional Committee of the Communist Party (Bolsheviks) of Ukraine $(\mathrm{CP}(\mathrm{b}) \mathrm{U})$ - is well preserved, with a number of underground documents found, most of them in copies and translations (orders, instructions, reports).

In the archive of the Center of the Study of the Liberation Movement, a significant source base was collected, based on the documents of the OUN and URA. A unique collection of documents is the so-called "Lebid's archive", formed on the basis of underground materials that were in emigration. A large array of OUN and URA documents found during Ukraine's independence is also in this archive of the institution.

The small P-9 fund contains only one description (16 cases) with educational and propaganda materials stored in the Central State Historical Archives of Ukraine in Lviv.

The array of propaganda literature was accumulated in fund 262 "The Organization of Ukrainian Nationalists and the Ukrainian Rebel Army" of the manuscripts department of the Lviv V. Stefanyk Scientific Library of the NAS of Ukraine. Thus, a large set of documents directly related to the functioning of the Ukrainian liberation movement in the OUN Carpathian region was kept in the home archive of Hryhoriy Demian, 
which was deposited to fund 262. It should be noted also the value of documents from the private archive of Zinovyi Boychuk.

It is also necessary to separate the documents of private archives, ascertain the presence of a whole layer of underground documents (mainly propaganda and reporting, sometimes instructive) and, importantly, photo illustrations accumulated in museums at different levels (regional, district, city, rural) of Transcarpathia, Ivano-Frankivsk, Lviv, Chernivtsi regions.

The searchers continue to find underground archives. For example, in 2002 in the village Tysiv Ivano-Frankivsk region they found an underground archive that was contained in two cans and consisted mostly of propaganda literature, leaflets, brochures, orders among them. In 2014, several cans of materials from the archives of the Sambir sub-district OUN provid were found in the Staryi Sambir region (in the neutral lane of the Ukrainian-Polish border), a large part of which is the materials of the Security System of of Nyzhnyi Ustryts OUN regional provid (1945-1947) and Strilky regional provid OUN. We consider it especially effective the founding of 2015, when was managed to find a collection of underground documents in the village Pistyn' of Kosiv district, as well as the archive of the OUN Kalush district provid.

The greater part of OUN and URA documents is published. The first such publications began to be published in OUN's foreign parts in the series "The Library of the Ukrainian Underground" (16 books), started in the 1950s. The mentioned collections contained leaflets and articles from underground members, and various programmatic and propaganda materials ${ }^{7}$.

A considerable array of the documents has been published in the fundamental documentary "The Chronicle of the Ukrainian Rebel Army". Today, two editions are published - the main one in 1975 in Canada (53 volumes were published till 2018) and the new one, which has been in print since 1995 in Kiev (28 volumes till 2018). Today, the URA Chronicle is the largest array of printed sources in the history of the Ukrainian liberation movement, joined in one edition. The main series of "The Chronicles of the URA" contain underground reports, official documents, as well as articles, memoirs and publications of historical and

\footnotetext{
${ }^{7}$ ОУН в світлі постанов Великих Зборів, Конференцій та інших документів з боротьби 1929-1955. [Б.м.]: Видання Закордонних частин ОУН, 1955. 372 с. (“Бібліотека українського підпільника” Ч. 1); УПА в світлі документів 3 боротьби за Українську Самостійну Соборну Державу 1942-1950 pp. [Б.м.]: Видання Закордонних частин ОУН, 1957. Ч. 1. 452 с. (Серія "Бібліотека українського підпільника" Ч. 6); УПА в світлі документів з боротьби за Українську Самостійну Соборну Державу 1942-1950 pр. Бойові дії УПА за 1943-1950 рр. [Б.м.]: Видання Закордонних частин ОУН, 1960. Ч. 2. 444 с. (Серія “Бібліотека українського підпільника" Ч. 7); УГВР в світлі постанов Великого Збору та інших документів 3 діяльности 1944-1951 pр. [Б.м.]: Видання Закордонних частин ОУН, 1956. 356 с. (Серія "Бібліотека українського підпільника" Ч. 3); АБН в світлі постанов Конференцій та інших матеріялів 3 діяльности 1941-1956 рр. [Б. м.]: Вид. ЗЧ ОУН, 1956. 368 с.
} 
memoir nature that are stored abroad. Of particular importance are the reports of individual administrative structures of the Ukrainian underground. In the context of the study of the topic identified, volumes 3, 4 "Chornyi Lis" ("The Black Forest") and 18, 19, entitled "Group URA "Hoverlia"8 are important. These volumes include reports and publications containing information on OUN and URA activities in the OUN Carpathian region. In the work the volumes devoted to the creation and activity of the Ukrainian General Liberation Council (UGLC) ${ }^{9}$, medical service ${ }^{10}$, construction and operation of hoods (bunkers) ${ }^{11}$ were used directly.

Unlike the main one, the new series of "The URA Chronicle" was printed in Ukraine is based on the documents of archival institutions of Ukraine. Among them are the collections of documents and materials of Bukovyna (compiled by Dmytro Prodanyk), Stanislav (compiled by D. Prodanyk ${ }^{12}$ and S. Lesiv) ${ }^{13}$ and Kolomyia district (compiled by D. Prodanyk, V. Humeniuk) $)^{14}$.

The specialist archeographic work is performed by Volodymir Serhiychuk for a long time. His compilations contain a large array of

8 Літопис Української Повстанської Армії. Т. 3: Чорний ліс: видання команди Станиславівського тактичного відтинка УПА 1947-1948 роки. Передрук підпільного журналу УПА (1947-1948) / [відп. ред. Є. Штендера, співред. П. Потічний]. Торонто: Літопис УПА, 1978. Кн. 1. 272 с.; Літопис Української Повстанської Армії. Т. 4: Чорний ліс: видання команди Станиславівського тактичного відтинка УПА 1947-1950 роки. (1948-1950) / [відп. ред. Є. Штендера, співред. П. Потічний]. Торонто: Літопис УПА, 1979. Кн. 2. 288 с.; Літопис Української Повстанської Армії. Т. 18: Група УПА “Говерля". Документи, звіти та офіційні публікації / [упоряд. Петро Содоль]. Торонто: Літопис УПА, 1990. Кн. 1. 328 с.; Літопис Української Повстанської Армії. Т. 19: Група УПА “Говерля". Спомини, статті та видання історично-мемуарного характеру / [упоряд. Петро Содоль]. Торонто; Львів: Літопис УПА, 1992. Кн. 2. 360 с.

9 Літопис Української Повстанської Армії. Т. 8: Українська Головна Визвольна Рада; документи, офіційні публікації, матеріали / [ред.-кол. Свген Штендера, Петро Потічний]. - Торонто: Літопис УПА, 1980. Кн. 1: 1944-1945. 320 с.; Літопис Української Повстанської Армії. Т. 9: Українська Головна Визвольна Рада. Документи, офіційні публікації, матеріяли / [ред.-кол. Свген Штендера, Петро Потічний]. Торонто: Літопис УПА, 1982. Кн. 2: 1946-1948. 520 с.; Літопис Української Повстанської Армії. Т. 10: Українська Головна Визвольна Рада. Документи, офіційні публікації, матеріяли / [ред.-кол. Свген Штендера, Петро Потічний]. Торонто: Літопис УПА, 1984. Кн. 3: 1949-1952. 424 с.; Літопис Української Повстанської Армії. Т. 24: Ідея і чин: Орган Проводу ОУН, 1942-1946 / [ред.кол. Юрій Маївський, Свген Штендера]. Торонто; Львів: Літопис УПА, 1996. 342 с.; Літопис Української Повстанської Армії. Т. 26: Українська Головна Визвольна Рада / [ред. Петро Потічний]. Торонто; Львів: Літопис УПА, 2001. Кн. 4: Документи і спогади. 658 с.

10 Літопис Української Повстанської Армії. Т. 23: Медична опіка в УПА [упоряд. Петро Содоль]. Торонто; Львів: Літопис УПА, 1992. 480 с.; Літопис Української Повстанської Армії. Т. 32: Медична опіка в УПА: документи, матеріяли і спогади / [ред. Модест Ріпецький]. Торонто; Львів: Літопис УПА, 2001. Кн. 2. 581 с.

${ }^{11}$ Літопис Української Повстанської Армії. Т. 38: Архітектура резистансу: криївки і бункери УПА в світлі радянських документів / [ред. Петро Потічний]. Торонто; Львів: Літопис УПА, 2002. 430 с.

12 Літопис Української Повстанської Армії. Нова серія. Т. 19: Підпілля ОУН на Буковині: Документи і матеріали. 1943-1951 / [упоряд. Дмитро Проданик]. К.; Торонто: Літопис УПА, 2012.840 с.

13 Літопис Української Повстанської Армії. Нова серія. Т. 22: Станиславівська округа ОУН: документи і матеріали 1945-1951 / [упоряд. Дмитро Проданик, Степан Лесів]. К.; Торонто: Літопис УПА, 2013. $1376 \mathrm{c}$.

14 Літопис Української Повстанської Армії. Нова серія. Т. 25: Коломийська округа ОУН: документи і матеріали 1945-1952 / [упоряд. Дмитро Проданик, Василь Гуменюк]. К.; Торонто: Літопис УПА, 2015. 1104 с. 
underground documents ${ }^{15}$. Some underground materials - program documents, orders, instructions, reports on the work done, appeals to the population - were published in the collection "Ukrainian National Liberation Movement in the Carpathian region in the XX century"16. Volodymyr Moroz published several important letters to the leaders of the nationalist movement concerning the creation of the Carpathian region ${ }^{17}$.

In the context of the study the official ethno-national policy of nationalists in the relation to representatives of other nationalities, the collection compiled by V. Panibudlaska matters ${ }^{18}$.

The collections of documents and materials on the Ukrainian-Polish confrontation are also very important that have been published over the last few years and edited by Volodymyr Viatrovych. The book includes littleknown documents that, in addition to a value of factual material about the persecution, make it possible to take a fresh approach to the study of the problems of the Polish-Ukrainian conflict ${ }^{19}$. The work of Vasyl Ilnytskyi and Mykola Haliv is dedicated to the activities of the Security Service in Drohobych region $^{20}$.

15 Сергійчук В. ОУН-УПА в роки війни. Нові документи і матеріали. К.: Дніпро, 1996. 496 с.; Сергійчук В. Сергійчук В. Десять буремних літ. Західноукраїнські землі у 1944-1953 рр. Нові документи і матеріали. К.: Дніпро, 1998. 944 с.; Сергійчук В. Український здвиг: Волинь. 1939-1955 рр. К.: Українська Видавнича Спілка, 2005. 840 с.; Сергійчук В. Український здвиг: Закерзоння. 1939-1947 рр. К.: Українська Видавнича Спілка, 2004. 836 с.; Сергійчук В. Український здвиг: Наддніпрянщина. 1941-1955 pр. К.: Українська Видавнича Спілка, 2005. 836 с.; Сергійчук В. Український здвиг: Поділля. 1939-1955 pр. К.: Українська Видавнича Спілка, 2005. 840 с.; Сергійчук В. Український здвиг: Прикарпаття. 1939-1955 рр. К.: Українська Видавнича Спілка, 2005. 840 с.; Роман Шухевич у документах радянських органів державної безпеки (1940-1950). К.: ПП Сергійчук М. І., 2007. Т. 1. 640 с.; Роман Шухевич у документах радянських органів державної безпеки (1940-1950). К.: ПП Сергійчук M. I., 2007. T. 2. 584 c.

16 Український національно-визвольний рух на Прикарпатті в XX столітті. Документи i матеріали / [відп. ред. проф. Микола Кугутяк]. Т. 2. Івано-Франківськ: КПФ “ЛІК”, 2009. Кн. 1: 1939-1945. 600 с.; Український національно-визвольний рух на Прикарпатті в ХХ столітті. Документи і матеріали / [відп. ред. проф. Микола Кугутяк]. Т. 2. Івано-Франківськ: КПФ “ЛІК”, 2010. Кн. 2: 1945-1946. 696 с.; Український національно-визвольний рух на Прикарпатті в ХХ столітті. Документи і матеріали / [відп. ред. проф. Микола Кугутяк]. Т. 2. Івано-Франківськ: КПФ “ЛІК”, 2011. Кн. 3 : 1947-1957. $768 \mathrm{c}$.

17 Мороз В. 3 листування членів Проводу ОУН (листопад 1944 - травень 1945) // Украӥнський визвольний рух. Львів, 2007. Збірник 10: До 100-річчя від дня народження Романа Шухевича. С. 34-52.

${ }^{18}$ Національні процеси в Україні: історія і сучасність. Документи і матеріали. Довідник: В 2 ч. / [упоряд. І. О. Кресіна (керівник), О.В.Кресів, В. П. Ляхоцький, В. П. Панібудьласка]. К.: Вища школа, 1997. Ч. 1. 583 с.; Національні процеси в Україні: історія і сучасність. Документи і матеріали. Довідник: В 2 ч. / [упоряд. І. О. Кресіна (керівник), О. В. Кресів, В. П. Ляхоцький, В. П. Панібудьласка]. К.: Вища школа, 1997. Ч. 2. 704 с.

19 Польсько-українські стосунки в 1942-1947 роках у документах ОУН та УПА: у 2 т./ [відп. ред. та упоряд. В. В’ятрович]. Львів: Центр досліджень визвольного руху, 2011. Т. 1: Війна під час війни (1942-1945). 792 с.; Польсько-українські стосунки в 1942-1947 роках у документах ОУН та УПА: у 2 т. / [відп. ред. та упоряд. В. В’ятрович]. Львів: Центр досліджень визвольного руху, 2011. Т. 2: Війна після війни (1945-1947). 576 с.

20 Діяльність Служби безпеки ОУН на Дрогобиччині: документи і матеріали (1944-1951) / [упоряд. Василь Ільницький, Микола Галів; передмова - Василь Ільницький, примітки - Микола Галів]. Кн. 1. Дрогобич: Швидкодрук, 2009. 264 с. 


\section{The documents of the repressive and punitive bodies of the USSR}

The second group of sources consists of documents of the repressivepunitive bodies of the USSR, which reflect the struggle of the special services against the structures of the OUN and URA, as well as the activities of nationalists against the approval of the authorities. Most of these documents, despite repeated large-scale destruction, are stored in the Sectoral State Archives of the Security Service of Ukraine. According to researchers and archivists, the Sectoral State Archives of the Security Service of Ukraine and its regional offices have "survived" at least three major "cleanups". The beginning was ordered (№ 00511, 1954) by the KGB head of the USSR, whose essence consisted in the necessity, during 1954-1955, to clear operational archives of "compromising" materials on "honest Soviet citizens, obtained through falsification and use of illegal methods of evidences". In fact, due to this order the documents that contained information about the extent of the repressive policy of the authorities against the national liberation movement were destroyed. Repeated "revision and ordering", as well as the destruction took place at the regular instruction of the center in 1960-1962. The last destruction was by the same order (№ 00150, 1990) of the KGB of the USSR. This time, archival materials that "do not represent operational value" were subject to destruction.

By the decree of the President of Ukraine of January 23, 2009, it was ordered the authorities to declassify archival documents related to the Ukrainian liberation movement, political repressions and famines in Ukraine. As a result, a number of archival funds were opened to the general public, shedding light on the struggle of the Soviet special services against the liberation movement, and scientists were given access to the documents of the fund 2 of the SSA SSU (fundraisers - control of the Banditry of the PCSS of the USSR in 1943-1946., department 2-N MSS of the USSR in 1947-1953 and the 4th KGB department of the USSR in 1953-1960). The bulk of the materials of the 2-N foundation are the documents of the Soviet state security bodies - reports, daily reports, search materials, orders, correspondence, agent reports ${ }^{21}$. The similar review documents of the Soviet punitive bodies are also contained in the

${ }^{21}$ ГДА СБУ. Ф. 2-Н. Оп. 54 (1953). Спр. 3. Т. 1. Арк. 260; Оп. 55 (1953). Спр. 5. Т. 1. Арк. 123-124, 190, 266, 347; Оп. 59 (1953). Спр. 7. Т. 2. Арк. 147-148; Оп. 60 (1953). Спр. 3. Т. 5. Арк. 186, 195-196; Оп. 67 (1953). Спр. 11. Арк. 33; Оп. 93 (1954). Спр. 1. Арк. 35, 47, 189, 238, 365, 377; Спр. 2. Арк. 35, 36; Оп. 98 (1954). Спр. 1. Т. 2. Арк. 47; Оп. 110 (1954). Спр. 2. Т. 5. Арк. 8, 24, 146-153, 154, 264-266, 269, 270; Т. 6. Арк. 214, 215; Т. 7. Арк. 8, 215-216, 221-225, 250; Т. 8. Арк. 243-244, 378; Оп. 28 (1960). Спр. 16. Арк. 136-138, 247; Т. 17. Арк. 14-15; Т. 20. Арк. 95-96, 98-99; Ф. 65. Спр. 7443. Арк. 232, 233, 267; Спр. 9079. Т. 52. Арк. 217-219; Ф. 71. Оп. 6. Спр. 203. Арк. 205; ЦДАГО України. Ф. 1. Оп. 23. Спр. 2968. Арк. 6-8. 
volumes of the already mentioned 372nd case of the 13th fund (extracts from reports, operative-search materials, orders, correspondence) ${ }^{22}$.

The most valuable are those documents of fund 2, which store daily records on the fight against underground in Ivano-Frankivsk, Transcarpathia, Drohobych, Chernivtsi regions, special messages, memos, notes. These reports were made by district and regional departments of 2-N immediately after the operation and contain detailed data of time, place, names of divisions, their heads, biographical data about the dead. The desire to report as soon as possible about the successful operation led to mistakes and inaccurate identification of the dead. In the fund, "Verkhovyntsi" multi-volume agency case (№ 304), instituted in December 1945 by the participants of the Carpathian Regional Leadership of the OUN, is of great importance. The case was implemented by the department of PCSS-MSS of Stanislav region, where it was stored until 1990, but due to the above-mentioned purges by the order of the KGB of the USSR (№ 00150 of 1990) it was completely destroyed. But in fund 2 of the SSA SSU a supervisory case on the work of the department of the Security Service of Ivano-Frankivsk region is remained. ${ }^{23}$ It contains documentation of UMSS of the Ivano-Frankivsk region of the MSS USSR for 1945-1954 the excerpts from investigative cases on the heads of the underground of the Carpathian regional provid, Kalush, Kolomyia, Stanislaviv district of OUN wires, instructions, orders, and a considerable array of important documents. In general, these documents reveal the stages and principles of organizing the liquidation of the governing structures of the underground of the Carpathian region.

The materials of the KGB department of Lviv region (f. 71), which contain documents from that part of the Carpathian region, are important.

The part of the documents of the punitive and repressive bodies of the USSR contains the analysis of the activities of the underground and measures to combat it. They make it possible today to reveal the mechanisms of real activity of the punitive bodies. It is also necessary to mention the documents f. 1 (2nd department of the MSS-KGB of the USSR), f. 3 (5th department of the MSS-KGB of the USSR) and f. 16 (the Secretariat of the SPU-KGB of the USSR). They contain supervisory cases on the fight against foreign intelligence agents, operational reporting by area (f. 1), various correspondence, control and surveillance cases on terrorist acts, briefing notes on agency and operative work (f. 3-5 department of the MSS-KGB of the USSR), copies of the summary

${ }^{22}$ ГДА СБУ. Ф. 13. Спр. 372. Т. 1. Арк. 227; Т. 2. Арк. 5-7; Т. 4. Арк. 245; Т. 5. Арк. 165-167; Т. 6. Арк. 38, 78; Т. 16. Арк. 273-275; Т. 18. Арк. 157-158; Т. 23. Арк. 400-422; Т. 26. Арк. 166-167; Т. 53. Арк. 232; Т. 56. Арк. 9-14, 131, 133, 169-170, 431-432; Т. 77. Арк. 131, 133, 371-376.

${ }^{23}$ ГДА СБУ. Ф. 2-Н. Оп. 110 (1954). Спр. 2. 
special messages, memos and submissions, the results of the fight against the OUN underground (f. 16).

The importance of the study of the functioning of the Ukrainian liberation movement in the Carpathian region of the OUN (1945 - 1954) contains f. 65 (cases of operational accounting of the KGB of the USSR), which contains the investigation and search cases on Petro Fedun ${ }^{24}$, Vasyl Sydor $^{25}$, Roman Tuchak ${ }^{26}$, as well as on the agent development of the Drohobych district of the OUN "Berloga"27. The materials of fund 65 are extremely important for the reconstruction of the circumstances of the death of the underground, as well as give an opportunity to highlight the methods and forms of work of special services. Among other things, it also contains the so-called case files for individual heads of the underground, to their cases agent data, extracts from underground documents and letters, excerpts from interrogation records, which mentioned the name of the person involved in the case and plans for his search and liquidation were primarily included.

The important information required for the reconstruction of the personnel of the region and district divisions of the PCHA-MHA and the PCSS-MSS, their quantitative and qualitative characteristics is contained in the personnel department of the KGB of the USSR (f. 8). The documents that reflect the functioning of the penitentiary system at the republican and regional levels (f. 20 - the KGB detention center of the USSR) are valuable. However, most cases with directives of prison departments of the PCHA of the USSR and the PCSS of the USSR to the heads of prison departments of the regional departments of the PCHA, correspondence of organs, memos, internal arrangements of prisons in the regions were destroyed.

The documents in the archives of the SSU departments of the Transcarpathia, Ivano-Frankivsk, Chernivtsi regions, which should have kept the materials of the PCSS-MSS with underground, were destroyed in the late 1980s and early 1990s. A somewhat different situation with the archival department of the SSU of Lviv region, in which materials from the PCSS-MSS-KGB of the Drohobych region were stored, was deposited in the SSA SSU in the late 1980s. Already there, some of the cases were destroyed. These are, first of all, the materials of all the regional divisions of the PCSS-MSS-KGB for the years 1939-1980, as well as the cases of

\footnotetext{
${ }^{24}$ ГДА СБУ. Ф. 65. Спр. 9112. Т. 17.

${ }^{25}$ ГДА СБУ. Ф. 65. Спр. 7443.

${ }^{26}$ ГДА СБУ. Ф. 65. Спр. 8707. Т. 1.

${ }^{27}$ ГДА СБУ. Ф. 65. Спр. С-9159; Спр. С-9186. Т. 1-2.
} 
the so-called activity of special groups ${ }^{28}$. Now the documents of the KGB directorate of Lviv region have been merged into 71 .

The documents of the punitive bodies contain considerable inaccuracies, during their drafting they were first guided by the desire to identify and prove the guilt of a person, to show the so-called "criminal" nature of their activity, and not to present the national liberation movement objectively. It should be emphasized that the criminal authorities reported what they knew what was needed first and foremost to eliminate the underground.

Obviously, the documents and materials of the Archival Directorates of the Ministry of Internal Affairs in the Transcarpathia, Ivano-Frankivsk, Lviv, Chernivtsi regions, in which thousands of cases of persons who were evicted to "remote areas of the USSR" can be found, are of great scientific and cognitive importance. Today, however, the funds of this archive remain to be classified as secret and are not accessible to researchers.

Archival-criminal cases (ACC), which make it possible not only to fill in the gaps in the structure of personal siege (fullness), but also to write in these biographies in the context of national liberation struggle simultaneously, to trace the forms and methods of combating the repressive and punitive system. When dealing with interrogation protocols, one should remember that this is a subjective source of information. It should be understood that the investigator tried to justify the accusations (confessions of the arrested was often enough to be justified), arrested - to hide as much as possible about himself, his activities and relatives, thereby protecting them from repression. In addition, all this happened under moral, psychological and physical constraints, which could only be resisted by one. In later years, the investigation was much more thoroughly conducted with the respect to the nationalists of the leading persons, the physical torture took a secondary or even a last place, instead a broader evidence base was gathered.

In SSA SSU in the Transcarpathia, Ivano-Frankivsk, Lviv and Chernivtsi regions, tens of thousands of archival criminal cases of convicted participants of liberation competitions have been accumulated. Of particular interest are the cases concerning the management of regional, district and sub-district provids, since their representatives were informed more than ordinary undergrounds. The cases of $\mathrm{f}$. 5 (criminal cases against non-rehabilitated persons) and f. 6 (criminal cases against rehabilitated persons) of SSA SSU, cases of the Department of Security System of Ukraine in Ivano Frankivsk region (DSSUIFR), the Department of Security System of Ukraine in Transcarpathia region (DSSUTR), the Department of

${ }^{28}$ ГДА СБУ. Ф. 71. Опис фонду. 
Security System of Ukraine in Lviv region (DSSULR), the Department of Security System of Ukraine in Chernivtsi region (DSSUCR).

It should also be noted that a number of persons, despite reliable information about their arrest, failed to identify criminal cases. Obviously, it did not start because the person went for open cooperation with punitive bodies or the case itself was destroyed or transferred to other institutions (for example, the Russian Federation).

Some separate interrogation protocols are contained in a number of volumes of the mentioned 372th case of fund 13. The further information on the undergrounds of Drohobych district is contained in interrogation protocols published in the ninth (Yaroslav-Dmitro Vitovskyi, Myroslav Haiduk, Artemizia Halytska, Oleksandr Lutskyi) and in the fifteenth (Julian Matviyiv, Mykola Krychun) volumes of the new series of "the URA Chronicles"29.

It is worth noting that, despite a number of inaccuracies, the interrogation protocols and other materials of criminal cases contain extremely valuable biographical information, the information about the structure and management.

Although according to the degree of authenticity of the information, the interrogation protocols are close to the memoirs, but they have not lost their value, because the information is recorded in "fresh footprints". However, it is marked by subjectivity, as it is usually received from an underground using physical torture, psychological pressure. In addition, the terminology in interrogation protocols and the use of the statements of an arrested person should be carefully considered. For example, all members of the national liberation movement were called "bandits", units of the URA were called "gangs", and supporters were called "band aides". Analyzing archival criminal cases, it was possible to find a large-scale calculation of the convictions. Despite the rejection of ideological stamps and layers, interrogation protocols after careful critical analysis can be considered as an important source for studying the history of the liberation struggle in the Carpathian region of the OUN.

A significant addition to the set of sources is the accounting records of fund 111 ("The Collection of Accounting and Personal Cases for Rehabilitated Special Settlers") of the Archival Sector of the Main Directorate of the National Police in Lviv region for families of

${ }^{29}$ Літопис Української Повстанської Армії. Нова серія. Т. 9: Боротьба проти повстанського руху і націоналістичного підпілля: протоколи допитів заарештованих радянськими органами державної безпеки керівників ОУН і УПА / [упоряд. Олександр Іщук, Сергій Кокін]. 1944-1945. К.; Торонто: Літопис УПА, 2007. 912 с.; Літопис Української Повстанської Армії. Нова серія. Т. 15: Боротьба проти повстанського руху і націоналістичного піпілля: протоколи допитів заарештованих радянськими органами державної безпеки керівників ОУН і УПА. 1945-1954 / [упоряд. С. Власенко, С. Кокін, В. Лозицький]. К.; Торонто: Літопис УПА, 2011. Кн. 2. 840 с. 
undergrounds and rebels who were deported to remote regions of the USSR, as well as on "expats" and "special settlers". The involvement of this category of cases, in particular the use of the indictments cited by them, gives grounds for claiming the use of hostages in the underground, gross falsification of cases and groundless mass repression. At the same time, the researcher's appeal to the materials of this fund is important informative for determining the time, place and circumstances of the death of certain undergrounds, the fate of their families, the output of statistics on the repression of the occupying power against the civilian population and the specifics of conducting deportation actions. The fund itself is not properly organized - several cases are stored under the same number, which can only be identified by name, although it would be more appropriate to divide cases into volumes.

The archives of Transcarpathia, Ivano-Frankivsk, Lviv, Chernivtsi regional offices of the search and publishing agency "The Memory Book of Ukraine", which stores files of thousands of people, based on processed data of archival-criminal cases, memoirs of participants and eyewitnesses to those events, which is certainly a great help in identifying nationalists, especially minor ones, are valuable for studying the staff of underground and underground structures.

The greater part of the punitive and repressive documents were published. One of the first was the collection, organized by Ivan Bilas, which contains documents on the activities of the repressive and punitive bodies to combat the underground of the Carpathian region of the $\mathrm{OUN}^{30}$. A number of materials of repressive and punitive bodies have been published in the already mentioned works of Volodymyr Serhiychuk. His subsequent works are also filled with the information that makes it possible to draw a holistic picture of the authorities' struggle against the underground ${ }^{31}$. To study the deportation policy of the Soviet administration, the three-volume document, generally edited by Yuri Slyvka, entitled "The Deportations: Western Lands of Ukraine in the late 1930s and early 1950s. Documents, Materials, Memories" is of particular value for the research ${ }^{32}$.

\footnotetext{
${ }^{30}$ Білас І. Репресивно-каральна система в Україні 1917-1953. Суспільно-політичний та історичний аналіз. У двох книгах. К.: Либідь; Військо України, 1994. Книга друга: Документи та матеріали. 688 с.

${ }^{31}$ Сергійчук В. Депортація поляків з України. Невідомі документи про насильницьке переселення більшовицькою владою польського населення з УРСР в Польщу в 1944-1946 роках. К.: Українська видавнича спілка, 1999. 191 с.; Сергійчук В. Самі себе звоювали. Діяльність винищувальних батальйонів проти українського національно-визвольного руху. К.: Українська видавнича спілка. 80 с.; Сергійчук В. Тавруючи визвольний прапор. Діяльність агентури та спецбоївок НКВС-НКДБ під виглядом ОУН-УПА. Видання друге, доповнене. К.: ПП Сергійчук М.I., 2006. 184 с.

32 Депортації: Західні землі України кінця 30-х-початку 50-х рр. Документи, матеріали, спогади. У трьох томах / [упоряд. Юрій Сливка]. Львів: Інститут українознавства імені Івана Крип’якевича НАН України, 1996. Т. 1: 1939-1945 pp. 750 с.; Депортації: Західні землі України кінця 30-х - початку 50-х рр. Документи, матеріали, спогади. У трьох томах. / [упоряд. Юрій Сливка]. Львів: Інститут українознавства імені Івана Крип’якевича НАН України, 1998. Т. 2: 1946-1947 pp. 540 с.
} 
One of the important sources is the documentary, which was published in the 1970s, and dedicated to the activities of border troops, which were entrusted not only with direct functions of state border protection, but also that often occurred at the initial stage of confrontation, struggle with the Ukrainian liberation movement. Since the Carpathian region covered the regions of the USSR, which bordered on a number of countries, much more forces were concentrated on its territory than on the territory of other regions ${ }^{33}$.

The collection of documents on the liberation struggle of 1944-1948 in the western regions of Ukraine is considered to be a significant supplement to the documentary base about the repressive activity of Soviet administration, which includes the collection of materials from so called "Special folders" of Joseph Stalin and Vyacheslav Molotov from the State Archives of the Russian Federation ${ }^{34}$.

The collections of documents published in Soviet times, contain tendered information, and therefore require a critical approach ${ }^{35}$. Since Ukraine's independence, they have been periodically appearing to exacerbate opposition in society ${ }^{36}$. Some materials in the history of the national liberation movement of the Carpathian region were selected for discrediting purpose. This include, published apparently for ideological war, a two-volume documentary, "The Ukrainian Nationalist Organizations in the Second World War," which contains 506 documents from 15 archives of Russia, Ukraine, Germany, Poland, Belarus ${ }^{37}$.

The article by Igor Marchuk ${ }^{38}$ is also of source importance, which provides an overview of the complex of documents of colonel Serhyi Stekhov stored in the holdings of the Rivne Museum of Local History (in 1947-1951 Serhyi Stekhov worked as head of the 2-N Department, in 1952-1953 - deputy head of the MSS department of Drohobych region).

33 Пограничные войска СССР 1945-1950. Сборник документов и материалов [ред. издат. А. Г. Синельников]. М.: Наука, 1975. 760 с.

34 “Особые папки” Сталіна і Молотова про національно-визвольну боротьбу в Західній Україні у 1944-1948 pр. / [упоряд. Ярослав Дашкевич; Василь Кук]. Львів: Піраміда, 2010. 594 с.

${ }^{35}$ Внутренние войска в борьбе с буржуазным националистическим подпольем на заключительном этапе Великой Отечественной войны и в первые послевоенные годы / [составители: Владимир Некрасов, Владимир Кривец, Михаил Горбов, Самуил Штутман]. М.: ГУВВ, 1986. 319 с.

${ }^{36}$ НКВД-МВД СССР в борьбе с бандитизмом и вооруженным националистическим подпольем на Западной Украине, в Западной Беларуссии и Прибалтике (1939-1956) / Сборник документов. [составители: Н. И. Владимирцев, А. И. Кокурин]. М.: Обьдиненная редакция МВС России, 2008. 640 с.

37 Украинские националистические организации в годы Второй мировой войны. Документи: в 2 т. / [под ред. А. Н. Артизова]. М.: Российская политическая энциклопедия (РОССПЭН), 2012. Т. 1: 1939-1943. 878 с.; Украинские националистические организации в годы Второй мировой войны. Документи: в 2 т./[под ред. А. Н. Артизова]. М.: Российская политическая энциклопедия (РОССПЭН), 2012. Т. 2: 1944-1945. 1167 с.

${ }^{38}$ Марчук І. Досьє полковника Стехова // Визвольний илях. 2008. Кн. 3. С. 175-188. 


\section{The Documents of party bodies}

The third group of documentary sources are the documents of party bodies. However, it should be emphasized that Soviet documents are subjective. When using them, it is necessary to take into account significant ideological stratification. Most of them are stored in the Central State Historical Museum of Ukraine (former archive of the Institute of Party History under the Central Committee of the Communist Party of Ukraine). The importance of the study of the materials of this archive lies in the fact that it was the communes, district committees, regional committees that were responsible for an armed and ideological struggle against the OUN and the URA. In general, the documents of this archive make it possible to reproduce the policy of the Soviet administration regarding the Sovietization of the region, to create an administrative, repressive and punitive apparatus, to find out the peculiarities of activity, forms and methods of combating the liberation movement. Specifically, fund 1 contains mainly policy documents (resolutions of party bodies, joint resolutions of party and state departments, decisions, transcripts of meetings of the $\mathrm{CK} \mathrm{CP}(\mathrm{b}) \mathrm{U}, \mathrm{CP}(\mathrm{b}) \mathrm{U}$ committees of the western region), information content (information of $\mathrm{CP}(\mathrm{b}) \mathrm{U}$ committees, reports of the power ministries), daily reports, special messages, information. These include the decision of the CK CP(b)U on the intensification of the struggle against Ukrainian nationalists and the shortcomings in the fight against them, the content of the secretaries of the primary party organizations and the results of the elections in the primary party organizations. The statistical reports of city councils, district committees of the Communist Party of Drohobych, Transcarpathia, Ivano-Frankivsk, Chernivtsi regional committees of the $\mathrm{CP}(\mathrm{b}) \mathrm{U}$ about the quantity of members, workers in certain spheres and the number of joined to the party. The part of the documents are copies and stored in the regional archives. In addition, analyzing the nature of the documents, we can state that they are the same as the materials found in SALR. Those that remained in place, after the collapse of the Soviet Union, were to be deposited in state archives. Drohobych, Transcarpathia, Ivano-Frankivsk, Chernivtsi regional committees of the $\mathrm{CP}(\mathrm{b}) \mathrm{U}$ prepared documents in several copies, one of which was sent to the Central Committee of the CP(b)U. Those that remained in regions, after the collapse of the Soviet Union, were to be deposited in state archives.

It should be noted that, immediately and partially after the collapse of the USSR, the so-called scrapping of "unwanted" documents was carried out both in the system of party (state) and KGB archives. As a result, a large array of documents was destroyed by the local staff, under the close 
supervision of colleagues at the center. Almost all the materials of the state archives of Transcarpathia, Chernivtsi regions on the fight against the PCIA-MIA and PCSS-MSS were gradually destroyed in October 1990. This is evidenced by the descriptions of the funds, which indicate the number of acts and the date of destruction against the respective category of cases. The documents of the party archives in the mentioned areas were cleaned professionally. A somewhat different situation in the State Archives of Ivano-Frankivsk region (SAIFR). The description was rewritten and no trace of destruction left. Although it is clear that the absence of a vast array of materials on the struggle of the authorities with the liberation movement is due to their elimination. There are no special files concerning special messages, reports on the fight in the SAIFR. Instead, a considerable number of them are preserved in the State Archives of Lviv region (SALR). Such data can only be obtained from the protocols of the meetings of the Stanislav department CP(b)U. Unlike Transcarpathia and Chernivtsi regions, in the SAIFR, probably because of the vast array of materials, the cases are preserved that indirectly reflect the activities of the OUN and the URA. This is mostly true of the documents covering the elections to the Supreme Soviet of the USSR, the fight of the underground against collectivization, the Komsomol, and so on. For the most part, there are cases in which the headlines did not explicitly mention the struggle against the nationalists and which do not contain a document on the crimes of the repressive and punitive system. The processing of descriptions allows to trace the extent of destruction of documents of the underground and repressive bodies, the correspondence of the Ministry of Internal Affairs with regional committees, district committees of the party and military units, prosecutor's office and court, materials of special check of the personnel of state bodies, activities of military tribunals, the materials of the elections to the Supreme Soviet of the USSR, the appeals and complaints of "workers" were varnished ${ }^{39}$. The rapid execution of orders and the extent of the destruction led to the fact that in the state archives of Transcarpathia and Chernivtsi regions it was not made appropriate markings in the descriptions, so it is impossible to find out the real picture p $^{40}$

The party documents on the struggle of the authorities with the nationalists are best preserved in the SALR (F. P-5001: Drohobych Regional Committee of the Communist Party (bolsheviks) of Ukraine $(\mathrm{CP}(\mathrm{b}) \mathrm{U})$, since October 1952 - CPU). It contains 12529 cases,

\footnotetext{
39 ДАІФО. Ф. 1. Оп. 1. Т. 1 (1946-1950 рр.). 140 арк.

40 ДАЧО. Ф. П-15. Оп. 1. Опис (1940-1971 рр.). 129 арк.; ДАЗО. Ф. П-1. Оп. 1. Опис (1946-1950). 140 арк.
} 
chronologically covering the years 1939-1941, 1943-1959 and containing transcripts and protocols of party meetings at different levels, the information on the preparation and holding of elections, special reports of the Ministry of Internal Affairs and information of the RC, MC, and the $\mathrm{CP}(\mathrm{b}) \mathrm{U}$ about the fight against the liberation movement. It was the party organs - regional committees, city committees and district committees which organized a large-scale armed and ideological struggle against the Ukrainian liberation movement, and under their leadership a repressive and punitive apparatus, which directly eliminated the underground. The overwhelming majority of the documents are memos of the Communist Party of Ukraine, the PCIA administration, the information of party district committees, the transcripts of meetings of party district secretaries, the information on the content of meetings on which issues were raised against Ukrainian nationalists, the staff of the secretaries of the primary party organizations and the results of the elections in primary party organizations. There is some informational in the statistic reports of city committees, district committees of the $\mathrm{CP}(\mathrm{b}) \mathrm{U}$ in Drohobych region about the number of members and candidates of the $\mathrm{CCP}(\mathrm{b})$ who work in certain sectors of the national economy, and about the number of candidates admitted to the party. There is the information about the number of underground fights, their characteristics, descriptions of armed attacks, prompt reports of the carried out operations, the lists of killed, captured, the information about the age of URA participants, the evictions of URA members' families, clearing of collective farms from unreliable persons, open trials over the participants of the URA (1949 p.). The important information was obtained from the memos of the PCIA-PCSS authorities not only on the course of the fight against the OUN and URA, but also on the quantitative status of the underground OUN and URA, the forms and methods of the fight against Soviet regime.

The cases in the State Archives of Transcarpathia Region (SATR) concerning the activities and combating underground were destroyed in October $1990^{41}$. A similar situation occurred in the State Archives of Chernivtsi region (SACR). The issues related to the fight against the underground and brought to the discussion of the regional council were added by separate documents that could not be found. At the same time, although it was "cleaned", in the State Archives of Ivano-Frankivsk Oblast (SAIFR) it was managed to find the information about the fight in the socalled protocol part of the committees and district committees. The documents from the funds of the Stanislav Regional Party (F. P-1), the Regional Executive Committee (F. P-295), the Regional Prosecutor's

${ }^{41}$ ДАЗО. Ф. П-1. Оп. 1. Арк. 7-9, 18, 25-27, 43, 60-61, 76, 90, 139 арк. 
Office (F. P-584), the Regional Military Commissariat (F. P-753) were also searched and processed. Among the sources found are resolutions, reporting documentation to higher party bodies, orders, information, analytical and statistical information.

In the state archives of Ivano-Frankivsk, Transcarpathia and Chernivtsi regions, among well-preserved documents, scripts and protocols of the meetings of the region and district party assets, political information, reports on the state and directions of development of industry and agriculture, advocacy work among the population, advocacy work with personnel, the information on the preparation and holding of elections to the Supreme Soviet of the USSR and local councils are of great importance. In other words, the documents on political, socio-economic and cultural development of these areas have been preserved. However, the information on the fight against the underground has been drawn from the general context.

When working with party documents of the specified category, they should be carefully separated through the ideological stamps and propaganda load they are saturated with: about "Ukrainian-German nationalists", "gangs of Ukrainian-German mercenaries", cooperation with special services of Germany, England, USA, etc.

The Institute of History of Ukraine of the NAS of Ukraine ${ }^{42}$ conducts considerable archaeographic work on the preparation and introduction to scientific circulation of the documents that cover the features and scope of the confrontation of the Ukrainian liberation movement with the Soviet totalitarian system. By their nature, both party and documents of the repressive and punitive bodies are included in the published collections.

A significant number of party documents from the archival institutions of Ukraine have been published in the new series of "the Chronicles of the URA" ${ }^{\prime 43}$, primarily from the funds of the State Historical and Historical

42 ОУН і УПА в 1945 році: Збірник документів і матеріалів. В 2 ч. Ч. 1 / [упоряд.: Веселова О.М. (відп. упоряд.), Гриневич В.А., Сергійчук В.І.; вступ: Лисенко О.С.]. К.: Інститут історії України НАН України, 2015. 371 с.; ОУН і УПА в 1945 році: Збірник документів і матеріалів. В 2 ч. Ч. 2 / [упоряд.: Веселова О.М. (відп. упоряд.), Гриневич В.А., Сергійчук В.І.]. К.: Інститут історії України НАН України, 2015. 366 с.

43 Літопис Української Повстанської Армії. Нова серія. Т. 3: Боротьба проти УПА і націоналістичного підпілля: директивні документи ЦК Компартії України. 1943-1959 / [упоряд. Олександр Вовк, Іван Павленко, Юрій Черченко]. К.; Торонто: Літопис УПА, 2001. 650 с.; Літопис Української Повстанської Армії. Нова серія. Т. 4: Боротьба проти УПА і націоналістичного підпілля: інформаційні документи ЦК КП(б)У, обкомів партії, НКВС-МВС, МДБ-КДБ (1943-1959) / [упоряд. Анатолій Кентій, Володимир Лозицький, Ірина Павленко]. К.; Торонто: Літопис УПА, 2002. Кн. 1: 1943-1945. 596 с.; Літопис Української Повстанської Армії. Нова серія. Т. 5: Боротьба проти УПА і націоналістичного підпілля: інформаційні документи ЦК КП(б)У, обкомів партії, НКВС-МВС, МДБ-КДБ (1943-1959) / [упоряд. Анатолій Кентій, Володимир Лозицький, Ірина Павленко]. К.; Торонто: Літопис УПА, 2002. Кн. 2: 1946-1947. 572 с.; Літопис Української Повстанської Армії. Нова серія. Т. 6: Боротьба проти УПА і націоналістичного підпілля: інформаційні документи ЦК КП(б)У, обкомів партії, НКВС-МВС, МДБ-КДБ (1943-1959) / [упоряд. Анатолій Кентій, Володимир Лозицький, Ірина Павленко, Катерина Абрамова]. К.; Торонто: Літопис УПА, 2003. Кн. 3: 1948. 523 с.; Літопис Української Повстанської Армії. Нова серія. Т. 7: Боротьба проти УПА i націоналістичного підпілля: інформаційні документи ЦК КП(б)У, обкомів партії, НКВС-МВС, МДБ-КДБ (1943-1959) / [упоряд. Михайло Деркач, Анатолій Кентій, Володимир Лозицький, Ірина Павленко]. К.; Торонто: Літопис УПА, 2003. Кн. 4: 1949-1959. 716 с. 
Museum of Ukraine. The documents are extremely important for covering the organization, forms and methods of the authorities' struggle against the underground of the Carpathian Regional Lead.

One of the first extensive archaeographic activities in the publication of party documents was launched by the famous researcher of the history of the liberation movement, Volodymyr Sergiychuk. A certain step forward, in comparison with the documentary works of his predecessors, was his collection, "OUN-URA in the Years of War", which was published in 1996. The book consists of a large number of underground, Soviet and German documents. The scientist continued his work on publication of documents in the following years. In particular, in an orderly collection of "Ten stormy years. Western Ukrainian Lands in 1944-1953" a large number of party documents is contained ${ }^{44}$. Extremely valuable are the documents collected by V. Sergiyuk were published in the collection under the general title "The Ukrainian Shift" 45 .

A large array of previously classified party documents revealing the scope of the struggle of the repressive-punitive apparatus against the liberation movement is centered in the three-volume "The Chronicle of Irresistible Ukraine", published under the general direction of Yaroslav Lyal'ka. However, the first two volumes have source value ${ }^{46}$. Also many memoirs of participants and eyewitnesses of the national liberation movement about the liberation struggle in the Carpathian region are published in these collections.

During the Soviet period, a number of published collections of documents on the Ukrainian liberation movement of the 1940s and 1950s were published, which are still being published. Their goal is to discredit, to denigrate the liberation struggle of national heroes, while rejecting the desire of Ukrainians to have their own state ${ }^{47}$.

${ }^{44}$ Сергійчук В. ОУН-УПА в роки війни. Нові документи і матеріали. К.: Дніпро, 1996. 496 с.; Сергійчук В. Десять буремних літ. Західноукраїнські землі у 1944-1953 pp. Нові документи і матеріали. К.: Дніпро, 1998. 944 с.

${ }^{45}$ Сергійчук В. Український здвиг: Волинь. 1939-1955 рр. К.: Українська Видавнича Спілка, 2005. 840 с.; Сергійчук В. Український здвиг: Закерзоння. 1939-1947 рр. К.: Українська Видавнича Спілка, 2004. 836 с.; Сергійчук В. Український здвиг: Наддніпрянщина. 1941-1955 pp. К.: Українська Видавнича Спілка, 2005. 836 с.; Сергійчук В. Український здвиг: Поділля. 1939-1955 рр. К.: Українська Видавнича Спілка, 2005. 840 с.; Сергійчук В. Український здвиг: Прикарпаття. 1939-1955 рр. К.: Українська Видавнича Спілка, 2005. 840 с.

46 Літопис нескореної України: Документи, матеріали, спогади / [підготували Ярослав Лялька, Петро Максимчук, Іван Патер та ін.; авт. передмови Ярослав Лялька, Роман Бачинський]. Львів: Просвіта, 1993. Кн. 1. 800 с.; Літопис нескореної України: Документи, матеріали, спогади / [підготували Ярослав Лялька, Роман Коритко, Мирон Онишкевич та ін.; авт. передмови Ярослав Лялька]. Львів: Галицька видавнича спілка, 1997. Кн. 2. 664 с.

47 Обвиняет земля. Организация украинских националистов: документы и материалы / [ред.-кол.: Виталий Масловский, Адам Мартынюк, Андрей Писловский, Владимир Помогаев, Руслан Пыриг]. М.: Универсум, 1991. 157 с. 


\section{The memories of participants of the Ukrainian national liberation movement}

The memoirs of the participants of the Ukrainian national liberation movement are an important source of comprehensive research, as they contain the characteristics of structure, leadership, reveal the forms and methods of the OUN's struggle against the establishment of the Soviet regime, and reveal the repressive policy of the official authorities against the underground. It should be emphasized that memoirs, although subjective, are not biased in some places, so the information must be carefully checked, and critically and comparatively analyzed. Instead, memories also have their advantage, because they convey the spirit of the time, the atmosphere of struggle, and provide the information that at one time could not be recorded in the documents of the underground or punitive bodies. A considerable number of them were written by the direct participants of the national liberation movement in "hot pursuit". An example is a sufficiently detailed biographical sketch of a SS referent, and hence the leader of the Dublin OUN District Office, Mikhailo Khariv "Shugay" 48 . Most notably, when writing a work on memoir sources, the work of the organizational referent of the OUN Stanislav districtprovid (07-08.1951), Petro Melnik "Khmara"49 was used. Following the instructions of the provid, he prepared his own memoirs, which have survived to this day. Equally valuable to us was the work of Stepan Frasuliak "Khmil" "50 the chief of military district (MD) "Hoverla" (1944). About his stay in the headquarters of the MD 5 "Makivka" wrote Stepan Fedorivskyi $^{51}$. The printer of OUN propaganda chief office Dariya Malyarchyn-Shpytal paid considerable attention to the rebels from Skole district $^{52}$.

In 2003, a collection of memoirs of the members of Drohobych OUN and the URA brotherhood under the title "You Will Get... or You Will Die..." 53 was started. The next collection under the same title was

\footnotetext{
${ }^{48}$ ГДА СБУ. Ф. 13. Спр. 376. Т. 47. Арк. 364-373.

49 Мельник Петро сотник УПА П. Хмара. В огні повстання. УПА на відтинку Чорного Лісу (1943-1945). Перша частина / [упоряд. Степан Лесів, Ярослав Коретчук]. Калуш: Карпатський акцент, 2014. $272 \mathrm{c}$.

${ }^{50}$ Ремесло повстанця. Збірник праць підполковника УПА Степана Фрасуляка-“Хмеля" / [ред. і упоряд. Р. Забілий]. Львів: Центр досліджень визвольного руху, 2007. 424 с.

${ }_{51}^{51}$ Федорівський С. Нотатки повстанця. Нью-Йорк: Прометей, 1962. 207 с.

52 I стали нам ті наші гори твердинею у лютий час... Спогади друкарки Головного осередку пропаганди ОУН і УПА Дарії Малярчин-Шпиталь / [ред.-упоряд. С. Онуфрів]. Львів: ПАІС, 2012. 164 с.; Малярчин-Шпиталь Д. Пам'яті Богдани Світлик // Пропам'ятна книга гімназї сестер Василіянок у Львові. Частина третя. Львів: Основа, 1995. С. 82-85.

53 “Здобудеш... або загинеш...” (Спогади ветеранів ОУН-УПА та наукові статті про національновизвольну боротьбу в 1940-1950-х рр. на Дрогобиччині) / [упоряд. Юрій Кишакевич]. Дрогобич: НВЦ “Каменяр” ДДПУ, 2003. Кн. 1. 172 с.
} 
published in $2007^{54}$. In the result of the field researches, the memories of direct participants and eyewitnesses of the national liberation movement were collected, organized and systematized, which became a kind of the continuation of the publications of memoirs, biographical references and martyrologists concerning the territory of the former Drohobych, Stanislav oblasts. These materials were enclosed in the book of memoirs "The Burning Way", edited by Vasily Ilnytskyi and Mykola Galiv". Dmytro Khorkavtsiv's reminiscences are rather informative, since they do not only cover the peculiarities of the life and preparation of the rebels, but also give unique testimonies of battles and persons information which were still unknown. Many memories relate to the life of the rebels, their clothing, food, wintering in the hiding places. The stories about the ways and methods of the Soviet special services' struggle with the nationalist underground are quite rich and detailed.

An important source for the study of the problem of functioning of the Ukrainian liberation movement in the OUN Carpathian region are the memoirs of the supporters Mariya Savchyn "Marichka", Stepan Stebelskyi "Hryn" and Oleksa Konopadskyi "Ostroverkh",57, published in the volumes of "The Chronicle of the URA. The book of memoirs about Mykola Tverdohlib "Grim" 58 was used in the monograph.

It is worth mentioning the historical and memoir trilogy of M. Andrusiak ${ }^{59}$. Despite the inaccuracies of the factual material and the fictional presentation, the memoir materials involved and the photoillustrated material collected are valuable.

Some researchers, including the author of this work, wrote down memories of participants in the liberation struggle of the 1940s and 1950s, who were directly related to the activities of the Carpathian region of the OUN. These records are kept in the private archives of those who carried them. Many of the collected and found memories relate to the everyday aspects of the life of the rebels, their clothing, food, wintering in the hiding places.

54 “Здобудеш... або загинеш...” (Спогади ветеранів ОУН-УПА про національно-визвольну боротьбу в 1940-1950-х pр. на Дрогобиччині) / [упоряд. Юрій Кишакевич, Микола Галів]. Дрогобич: Ред.-вид. відділ Дрогобицького державного педагогічного університету імені Івана Франка, 2007. Кн. 2. 190 с.

55 Шлях горіння: Спогади ветеранів ОУН і УПА про національно-визвольну боротьбу в 1940-1950-х рр. / [упоряд. Микола Галів, Василь Ільницький]. Дрогобич: Посвіт, 2008. 520 с.

56 Марія Савчин ("Марічка"). Тисячі доріг (Спогади) // Літопис Української повстанської армії [ред.-кол. Свген Штендера, Петро Потічний]. Торонто; Львів: Літопис УПА, 1995. Т. 28. 598 с.

57 Літопис Української Повстанської Армії. Т. 30: Степан Хрін (Степан Стебельський); Крізь сміх заліза: спогади / [ред. Петро Потічний]. Торонто: Літопис УПА, 2000. 552 с.

58 "Грім"- полковник УПА Микола Твердохліб. Спогади і матеріали / [упоряд. Грицьків Р.]. Торонто; Львів: Літопис УПА, 2008. Кн. 5.128 с. (Літопис УПА. Серія “Події і люди”).

${ }_{59}$ Андрусяк М. Брати вогню. Коломия: Вік, 2004. 832 с.; Андрусяк М. Брати грому. Коломия: Вік, 2005. 832 с.; Андрусяк М. Брати просторів. Коломия: Вік, 2007. 840 с; Андрусяк М. Грані болю [Текст]: док. оповіді про УПА. Коломия: Вік, 1994. 198 с. 
To important, extremely informative sources that help to cover this problem in the complex are included personal documents, epistolary art, photos, things of the underground and their relatives, graves with corresponding inscriptions, hiding places, as well as the remains of underground archives. A unique photo archive was managed to organize and process by Vasily Humeniuk ${ }^{60}$. These photos, in addition to transmitting of images of the insurgents themselves, complement significantly the notion of daily life, weapons, and partly the relationship among nationalists.

\section{Periodicals}

We cannot avoid such a valuable source for covering the topic of the study as the periodicals (official Soviet and OUN and URA). It is clear that the Soviet press pursued a party line that had the task of carrying out propaganda treatment of the population and combating the ideology of nationalism. The paper also used publications from periodicals and underground press and the OUN's press bodies, including the underground and insurgent publications "Idea i Chyn" ("Idea and Post"), "Shlyah peremogy" ("The Way of Victory"), "Chornyi Lis" ("The Black Forest"), "Revolucioner-propagandyst" ("A Revolutionary-Proponent"), "Do Zbroii" ("To Arms")", Povstanets" ("A Rebel") and Soviet editions (newspapers of regional $\mathrm{CP}(\mathrm{b}) \mathrm{U}$ "Zakarpatska Pravda", "Soviet Bukovina", "A Soviet Word", "Precarpathian Pravda", as well as regional periodicals) ${ }^{61}$.

\section{CONCLUSIONS}

Thus, the decades-long rebel struggle in the Carpathian region (1945-1954) left a huge documentary legacy. The archives of different levels contain documents that comprehensively characterize the liberation struggle of the Ukrainian people. The presence of various documents by origin, authenticity and content of documents makes it possible to study different aspects of the activities of the national liberation movement systematically, to recreate its structure and to show the directions of repressive policy of the authorities towards the nationalists of the Carpathian region of the OUN (second half of the 40s - the first half of the 1950s). At the same time, it should be remembered that the widest possible and comprehensive use of different types of sources, their comparison

${ }^{60}$ Гуменюк В., Яким’юк С. Повстанські світлини зі сховку Володимира Яким'юка “Аскольда”. Львів: ПП Сорока Т.Б., 2007. 144 с.; Гуменюк В., Яким’юк С. Повстанські світлини зі сховку Володимира Якимюка “Аскольда". Львів: ПП Сорока Т.Б., 2007. 144 с.; Гуменюк В. Фотограф УПА “Липкевич”// Украӥнський визвольний рух. Львів: Мс, 2003. Збірник 1. С. 159-164.

61 Літопис Української Повстанської Армії. Нова серія. Т. 1: Видання Головного Командування УПА / [упоряд. Олександр Вовк, Василь Галаса, Юрій Черченко]. К.; Торонто: Літопис УПА, 1995. 482 с. 
makes it possible to verify the accuracy of the data and to ascertain the real situation in crayovyi provid of the OUN of the Carpathian region sufficiently and objectively.

\section{SUMMARY}

It is established that as a result of the 10-year rebel struggle in the Carpathian region (1945-1954), there is a huge documentary heritage, characterized by origin, place of storage, representativeness of historical facts, manning methods, degree of disclosure of certain aspects of the problem. Depending on the origin or authorship in the broad sense, the whole source complex can be divided into five groups: 1) OUN and URA documents; 2) The documents of the repressive and punitive bodies of the USSR; 3) The documents of party bodies; 4) The memories of the participants of the Ukrainian national liberation movement; 5) periodicals. The presence of various documents by origin, authenticity and content of documents makes it possible to study different aspects of the activities of the national liberation movement systematically, to recreate its structure and to show the directions of repressive policy of the authorities towards the nationalists of the Carpathian region of the OUN (second half of the $40 \mathrm{~s}$ - the first half of the 1950s). At the same time, it should be remembered that the widest possible and comprehensive use of different types of sources, their comparison makes it possible to verify the accuracy of the data and to ascertain the real situation in crayovyi provid of the OUN of the Carpathian region sufficiently and objectively.

\section{REFERENCES}

1. АБН в світлі постанов Конференцій та інших матеріялів 3 діяльности 1941-1956 рр. [Б. м.]: Вид. ЗЧ ОУН, 1956. 368 с.

2. Андрусяк М. Брати просторів. Коломия: Вік, 2007. 840 с.

3. Андрусяк М. Грані болю [Текст]: док. оповіді про УПА. Коломия: Вік, 1994. 198 с.

4. Андрусяк М. Брати вогню. Коломия: Вік, 2004. 832 с.

5. Андрусяк М. Брати грому. Коломия: Вік, 2005. 832 с.

6. Білас I. Репресивно-каральна система в Україні 1917-1953. Суспільно-політичний та історичний аналіз. У двох книгах. К.: Либідь; Військо України, 1994. Книга друга: Документи та матеріали. $688 \mathrm{c}$.

7. Внутренние войска в борьбе с буржуазным националистическим подпольем на заключительном этапе Великой Отечественной войны и в первые послевоенные годы / [составители: Владимир 
Некрасов, Владимир Кривец, Михаил Горбов, Самуил Штутман]. М.: ГУВВ, 1986. 319 с.

8. Галузевий державний архів Служби безпеки України (далі ГДА СБУ). Ф. 2-Н. Оп. 54 (1953). Спр. 3. Т. 1.

9. ГДА СБУ. Ф. 2-Н. Оп. 55 (1953). Спр. 5. Т. 1.

10. ГДА СБУ. Ф. 2-Н. Оп. 59 (1953). Спр. 6. Т. 4.

11. ГДА СБУ. Ф. 2-Н. Оп. 59 (1953). Спр. 7. Т. 2.

12. ГДА СБУ. Ф. 2-Н. Оп. 60 (1953). Спр. 3. Т. 5.

13. ГДА СБУ. Ф. 2-Н. Оп. 67 (1953). Спр. 11.

14. ГДА СБУ. Ф. 2-Н. Оп. 93 (1954). Спр. 1.

15. ГДА СБУ. Ф. 2-Н. Оп. 93 (1954). Спр. 2.

16. ГДА СБУ. Ф. 2-Н. Оп. 98 (1954). Спр. 1. Т. 2.

17. ГДА СБУ. Ф. 2-Н. Оп. 110 (1954). Спр. 2. Т. 5.

18. ГДА СБУ. Ф. 2-Н. ОП. 110 (1954). Спр. 2. Т. 6.

19. ГДА СБУ. Ф. 2-Н. Оп. 110 (1954). Спр. 2. Т. 7.

20. ГДА СБУ. Ф. 2-Н. Оп. 110 (1954). Спр. 2. Т. 8.

21. ГДА СБУ. Ф. 2-Н. Оп. 28 (1960). Спр. 16.

22. ГДА СБУ. Ф. 2-Н. Оп. 28 (1960). Спр. 17.

23. ГДА СБУ. Ф. 2-Н. Оп. 28 (1960). Спр. 20.

24. ГДА СБУ. Ф. 13. Спр. 372. Т. 1.

25. ГДА СБУ. Ф. 13. Спр. 372. Т. 2.

26. ГДА СБУ. Ф. 13. Спр. 372. Т. 4.

27. ГДА СБУ. Ф. 13. Спр. 372. Т. 5.

28. ГДА СБУ. Ф. 13. Спр. 372. Т. 6.

29. ГДА СБУ. Ф. 13. Спр. 372. Т. 9.

30. ГДА СБУ. Ф. 13. Спр. 372. Т. 16.

31. ГДА СБУ. Ф. 13. Спр. 372. Т. 18.

32. ГДА СБУ. Ф. 13. Спр. 372. Т. 23.

33. ГДА СБУ. Ф. 13. Спр. 372. Т. 26.

34. ГДА СБУ. Ф. 13. Спр. 372. Т. 53.

35. ГДА СБУ. Ф. 13. Спр. 372. Т. 56.

36. ГДА СБУ. Ф. 13. Спр. 372. Т. 77.

37. ГДА СБУ. Ф. 13. Спр. 376. Т. 47.

38. ГДА СБУ. Ф. 13. Спр. 398. Т. 13.

39. ГДА СБУ. Ф. 65. Спр. 9079. Т. 52.

40. ГДА СБУ. Ф. 65. Спр. 7443.

41. ГДА СБУ. Ф. 65. Спр. 7443.

42. ГДА СБУ. Ф. 65. Спр. 8707. Т. 1.

43. ГДА СБУ. Ф. 65. Спр. 9112. Т. 17.

44. ГДА СБУ. Ф. 65. Спр. С-9159.

45. ГДА СБУ. Ф. 65. Спр. С-9186. Т. 1-2. 
46. ГДА СБУ. Ф. 71. Оп. 6. Спр. 203.

47. ГДА СБУ. Ф. 71. Опис фонду.

48. "Грім"-полковник УПА Микола Твердохліб. Спогади i матеріали / [упоряд. Грицьків Р.]. Торонто; Львів: Літопис УПА, 2008. Кн. 5.128 с. (Літопис УПА. Серія "Події і люди”).

49. Гуменюк В. Фотограф УПА “Липкевич” // Украӥнський визвольний рух. Львів: Мс, 2003. Збірник 1. С. 159-164.

50. Гуменюк В., Яким'юк С. Повстанські світлини зі сховку Володимира Яким'юка “Аскольда”. Львів: ПП Сорока Т.Б., 2007. $144 \mathrm{c}$.

51. Гуменюк В., Яким'юк С. Повстанські світлини зі сховку Володимира Якимюка “Аскольда". Львів: ПП Сорока Т.Б., 2007. $144 \mathrm{c}$.

52. Державний архів Закарпатської області (далі - ДАЗО). Ф. П-1. Оп. 1. Опис (1946-1950).

53. Державний архів Івано-Франківської області (далі - ДАІФО). Ф. 1. Оп. 1. Т. 1 (1946-1950 рр.).

54. Державний архів Чернівецької області (далі - ДАЧО). Ф. П-15. Оп. 1. Опис (1940-1971 рр.).

55. Депортації: Західні землі України кінця 30-х - початку 50-х pp. Документи, матеріали, спогади. У трьох томах / [упоряд. Юрій Сливка]. Львів: Інститут українознавства імені Івана Крип'якевича НАН України, 1996. Т. 1: 1939-1945 pp. 750 с.

56. Депортації: Західні землі України кінця 30-х-початку 50-х рр. Документи, матеріали, спогади. У трьох томах. / [упоряд. Юрій Сливка]. Львів: Інститут українознавства імені Івана Крип'якевича НАН України, 1998. Т. 2: 1946-1947 pp. 540 с.

57. Діяльність Служби безпеки ОУН на Дрогобиччині: документи і матеріали (1944-1951) / [упоряд. Василь Ільницький, Микола Галів; передмова - Василь Ільницький, примітки - Микола Галів]. Кн. 1. Дрогобич: Швидкодрук, 2009. 264 с.

58. I стали нам ті наші гори твердинею у лютий час... Спогади друкарки Головного осередку пропаганди ОУН i УПА Дарії Малярчин-Шпиталь / [ред.-упоряд. С. Онуфрів]. Львів: ПАІС, 2012. 164 c.

59. “ Здобудеш... або загинеш...” (Спогади ветеранів ОУН-УПА та наукові статті про національно-визвольну боротьбу в 1940-1950-х рр. на Дрогобиччині) / [упоряд. Юрій Кишакевич]. Дрогобич: НВЦ “Каменяр” ДДПУ, 2003. Кн. 1. 172 с.

60. “Здобудеш... або загинеш...” (Спогади ветеранів ОУН-УПА про національно-визвольну боротьбу в 1940-1950-х pp. на 
Дрогобиччині) / [упоряд. Юрій Кишакевич, Микола Галів]. Дрогобич: Ред.-вид. відділ Дрогобицького державного педагогічного університету імені Івана Франка, 2007. Кн. 2. 190 с.

61. Літопис нескореної України: Документи, матеріали, спогади / [підготували Ярослав Лялька, Петро Максимчук, Іван Патер та ін.; авт. передмови Ярослав Лялька, Роман Бачинський]. Львів: Просвіта, 1993. Кн. 1.800 с.

62. Літопис нескореної України: Документи, матеріали, спогади / [підготували Ярослав Лялька, Роман Коритко, Мирон Онишкевич та ін.; авт. передмови Ярослав Лялька]. Львів: Галицька видавнича спілка, 1997. Кн. 2. 664 с.

63. Літопис Української Повстанської Армії. Т. 3: Чорний ліс: видання команди Станиславівського тактичного відтинка УПА 1947-1948 роки. Передрук підпільного журналу УПА (1947-1948) / [відп. ред. С. Штендера, співред. П. Потічний]. Торонто: Літопис УПА, 1978. Кн. 1. 272 с.

64. Літопис Української Повстанської Армії. Т. 4: Чорний ліс: видання команди Станиславівського тактичного відтинка УПА 1947-1950 роки. (1948-1950) / [відп. ред. С. Штендера, співред. П. Потічний]. Торонто: Літопис УПА, 1979. Кн. 2. 288 с.

65. Літопис Української Повстанської Армії. Т. 8: Українська Головна Визвольна Рада; документи, офіційні публікації, матеріали / [ред.-кол. Євген Штендера, Петро Потічний]. - Торонто: Літопис УПА, 1980. Кн. 1: 1944-1945. 320 с.

66. Літопис Української Повстанської Армії. Т. 9: Українська Головна Визвольна Рада. Документи, офіційні публікації, матеріяли / [ред.-кол. Свген Штендера, Петро Потічний]. Торонто: Літопис УПА, 1982. Кн. 2: 1946-1948. 520 с.

67. Літопис Української Повстанської Армії. Т. 10: Українська Головна Визвольна Рада. Документи, офіційні публікації, матеріяли / [ред.-кол. Свген Штендера, Петро Потічний]. Торонто: Літопис УПА, 1984. Кн. 3: 1949-1952. 424 с.

68. Літопис Української Повстанської Армії. Т. 18: Група УПА "Говерля". Документи, звіти та офіційні публікації / [упоряд. Петро Содоль]. Торонто: Літопис УПА, 1990. Кн. 1.328 с.

69. Літопис Української Повстанської Армії. Т. 19: Група УПА "Говерля". Спомини, статті та видання історично-мемуарного характеру / [упоряд. Петро Содоль]. Торонто; Львів: Літопис УПА, 1992. Кн. 2. 360 c. 
70. Літопис Української Повстанської Армії. Т. 23: Медична опіка в УПА [упоряд. Петро Содоль]. Торонто; Львів: Літопис УПА, 1992. $480 \mathrm{c}$.

71. Літопис Української Повстанської Армії. Т. 24: Ідея і чин: Орган Проводу ОУН, 1942-1946 / [ред.-кол. Юрій Маївський, Євген Штендера]. Торонто; Львів: Літопис УПА, 1996. 342 с.

72. Літопис Української Повстанської Армії. Т. 26: Українська Головна Визвольна Рада / [ред. Петро Потічний]. Торонто; Львів: Літопис УПА, 2001. Кн. 4: Документи і спогади. 658 с.

73. Літопис Української Повстанської Армії. Т. 30: Степан Хрін (Степан Стебельський); Крізь сміх заліза: спогади / [ред. Петро Потічний]. Торонто: Літопис УПА, 2000. 552 с.

74. Літопис Української Повстанської Армії. Т. 32: Медична опіка в УПА: документи, матеріяли і спогади / [ред. Модест Ріпецький]. Торонто; Львів: Літопис УПА, 2001. Кн. 2. 581 с.

75. Літопис Української Повстанської Армії. Т. 38: Архітектура резистансу: криївки і бункери УПА в світлі радянських документів / [ред. Петро Потічний]. Торонто; Львів: Літопис УПА, 2002. 430 с.

76. Літопис Української Повстанської Армії. Нова серія. Т. 1: Видання Головного Командування УПА / [упоряд. Олександр Вовк, Василь Галаса, Юрій Черченко]. К.; Торонто: Літопис УПА, 1995. $482 \mathrm{c}$.

77. Літопис Української Повстанської Армії. Нова серія. Т. 4: Боротьба проти УПА і націоналістичного підпілля: інформаційні документи ЦК КП(б)У, обкомів партії, НКВС-МВС, МДБ-КДБ (1943-1959) / [упоряд. Анатолій Кентій, Володимир Лозицький, Ірина Павленко]. К.; Торонто: Літопис УПА, 2002. Кн. 1: 1943-1945. 596 с.;

78. Літопис Української Повстанської Армії. Нова серія. Т. 5: Боротьба проти УПА і націоналістичного підпілля: інформаційні документи ЦК КП(б)У, обкомів партії, НКВС-МВС, МДБ-КДБ (1943-1959) / [упоряд. Анатолій Кентій, Володимир Лозицький, Ірина Павленко]. К.; Торонто: Літопис УПА, 2002. Кн. 2: 1946-1947. 572 с.

79. Літопис Української Повстанської Армії. Нова серія. Т. 6: Боротьба проти УПА і націоналістичного підпілля: інформаційні документи ЦК КП(б)У, обкомів партії, НКВС-МВС, МДБ-КДБ (1943-1959) / [упоряд. Анатолій Кентій, Володимир Лозицький, Ірина Павленко, Катерина Абрамова]. К.; Торонто: Літопис УПА, 2003. Кн. 3: 1948. 523 c.

80. Літопис Української Повстанської Армії. Нова серія. Т. 7: Боротьба проти УПА і націоналістичного підпілля: інформаційні документи ЦК КП(б)У, обкомів партії, НКВС-МВС, МДБ-КДБ 
(1943-1959) / [упоряд. Михайло Деркач, Анатолій Кентій, Володимир Лозицький, Ірина Павленко]. К.; Торонто: Літопис УПА, 2003. Кн. 4: 1949-1959. $716 \mathrm{c.}$

81. Літопис Української Повстанської Армії. Нова серія. Т. 9: Боротьба проти повстанського руху і націоналістичного підпілля: протоколи допитів заарештованих радянськими органами державної безпеки керівників ОУН і УПА / [упоряд. Олександр Іщук, Сергій Кокін]. 1944-1945. К.; Торонто: Літопис УПА, 2007. 912 с.

82. Літопис Української Повстанської Армії. Нова серія. Т. 15: Боротьба проти повстанського руху i націоналістичного піпілля: протоколи допитів заарештованих радянськими органами державної безпеки керівників ОУН і УПА. 1945-1954 / [упоряд. С. Власенко, С. Кокін, В. Лозицький]. К.; Торонто: Літопис УПА, 2011. Кн. 2.840 c.

83. Літопис Української Повстанської Армії. Нова серія. Т. 19: Підпілля ОУН на Буковині: Документи і матеріали. 1943-1951 / [упоряд. Дмитро Проданик]. К.; Торонто: Літопис УПА, 2012. 840 с.

84. Літопис Української Повстанської Армії. Нова серія. Т. 22: Станиславівська округа ОУН: документи і матеріали 1945-1951 / [упоряд. Дмитро Проданик, Степан Лесів]. К.; Торонто: Літопис УПА, 2013. $1376 \mathrm{c.}$

85. Літопис Української Повстанської Армії. Нова серія. Т. 25: Коломийська округа ОУН: документи і матеріали 1945-1952 / [упоряд. Дмитро Проданик, Василь Гуменюк]. К.; Торонто: Літопис УПА, 2015. $1104 \mathrm{c.}$

86. Літопис Української Повстанської Армії. Нова серія. Т. 3: Боротьба проти УПА i націоналістичного підпілля: директивні документи ЦК Компартії України. 1943-1959 / [упоряд. Олександр Вовк, Іван Павленко, Юрій Черченко]. К.; Торонто: Літопис УПА, $2001.650 \mathrm{c}$.

87. Малярчин-Шпиталь Д. Пам'яті Богдани Світлик // Пропам'ятна книга гімназї сестер Василіянок у Львові. Частина третя. Львів: Основа, 1995. С. 82-85.

88. Марія Савчин (“Марічка”). Тисячі доріг (Спогади) // Літопис Української повстанської армії [ред.-кол. Свген Штендера, Петро Потічний]. Торонто; Львів: Літопис УПА, 1995. Т. 28. 598 с.

89. Марчук І. Досьє полковника Стехова // Визвольний шлях. 2008. Кн. 3. С. 175-188.

90. Мельник Петро сотник УПА П. Хмара. В огні повстання. УПА на відтинку Чорного Лісу (1943-1945). Перша частина / 
[упоряд. Степан Лесів, Ярослав Коретчук]. Калуш: Карпатський акцент, 2014. 272 с.

91. Мороз В. 3 листування членів Проводу ОУН (листопад 1944 травень 1945) // Український визвольний рух. Львів, 2007. Збірник 10: До 100-річчя від дня народження Романа Шухевича. С. 34-52.

92. Національні процеси в Україні: історія і сучасність. Документи i матеріали. Довідник: В 2 ч. / [упоряд. I.О. Кресіна (керівник), О.В. Кресів, В.П. Ляхоцький, В.П. Панібудьласка]. К.: Вища школа, 1997. Ч. 1. 583 с.

93. Національні процеси в Україні: історія і сучасність. Документи і матеріали. Довідник: В 2 ч./ [упоряд. I. О. Кресіна (керівник), О.В. Кресів, В.П. Ляхоцький, В.П. Панібудьласка]. К.: Вища школа, 1997. Ч. 2.704 с.

94. НКВД-МВД СССР в борьбе с бандитизмом и вооруженным националистическим подпольем на Западной Украине, в Западной Беларуссии и Прибалтике (1939-1956) / Сборник документов. [составители: Н.И. Владимирцев, А.И. Кокурин]. М.: Обьдиненная редакция МВС России, 2008. 640 с.

95. Обвиняет земля. Организация украинских националистов: документы и материалы / [ред.-кол.: Виталий Масловский, Адам Мартынюк, Андрей Писловский, Владимир Помогаев, Руслан Пыриг]. М.: Универсум, 1991. 157 с.

96. “Особые папки” Сталіна і Молотова про національновизвольну боротьбу в Західній Україні у 1944-1948 рр./ [упоряд. Ярослав Дашкевич; Василь Кук]. Львів: Піраміда, 2010. $594 \mathrm{c}$.

97. ОУН в світлі постанов Великих Зборів, Конференцій та інших документів з боротьби 1929-1955. [Б.м.]: Видання Закордонних частин ОУН, 1955. 372 с. (“Бібліотека українського підпільника” Ч. 1).

98. ОУН і УПА в 1945 році: Збірник документів і матеріалів. В 2 ч. Ч. 1 / [упоряд.: Веселова О.М. (відп. упоряд.), Гриневич В.А., Сергійчук В.I.; вступ: Лисенко О.С.]. К.: Інститут історії України НАН України, 2015. 371 с.

99. ОУН і УПА в 1945 році: Збірник документів і матеріалів. В 2 ч. Ч. 2 / [упоряд.: Веселова О. М. (відп. упоряд.), Гриневич В.А., Сергійчук В.I.]. К.: Інститут історії України НАН України, 2015. $366 \mathrm{c.}$

100. Папакін Г. Українські визвольні змагання 1939-1956: джерельний контент. Вип. 1. Проблеми класифікації й змісту джерел повстанського та радянського походження / [відп. ред. Г. Боряк] / Інститут історії України НАН України. К., 2012. 358 с. 
101. Пограничные войска СССР 1945-1950. Сборник документов и материалов [ред. издат. А. Г. Синельников]. М.: Наука, 1975. 760 с.

102. Польсько-українські стосунки в 1942-1947 роках у документах ОУН та УПА: у 2 т. / [відп. ред. та упоряд. В. В'ятрович]. Львів: Центр досліджень визвольного руху, 2011. Т. 1: Війна під час війни (1942-1945). 792 с.

103. Польсько-українські стосунки в 1942-1947 роках у документах ОУН та УПА: у 2 т. / [відп. ред. та упоряд. В. В'ятрович]. Львів: Центр досліджень визвольного руху, 2011. Т. 2: Війна після війни (1945-1947). 576 с.

104. Ремесло повстанця. Збірник праць підполковника УПА Степана Фрасуляка - "Хмеля" / [ред. і упоряд. Р. Забілий]. Львів: Центр досліджень визвольного руху, 2007. 424 с.

105. Роман Шухевич у документах радянських органів державної безпеки (1940-1950). К.: ПП Сергійчук М. I., 2007. Т. 1. $640 \mathrm{c.}$

106. Роман Шухевич у документах радянських органів державної безпеки (1940-1950). К.: ПП Сергійчук М. I., 2007. T. 2.584 c.

107. Сергійчук В. Десять буремних літ. Західноукраїнські землі у 1944-1953 pр. Нові документи і матеріали. К.: Дніпро, 1998. 944 с.

108. Сергійчук В. Депортація поляків 3 України. Невідомі документи про насильницьке переселення більшовицькою владою польського населення з УРСР в Польщу в 1944-1946 роках. К.: Українська видавнича спілка, 1999. 191 с.; Сергійчук В. Самі себе звоювали. Діяльність винищувальних батальйонів проти українського національно-визвольного руху. К.: Українська видавнича спілка. 80 с.

109. Сергійчук В. ОУН-УПА в роки війни. Нові документи i матеріали. К.: Дніпро, 1996. 496 с.

110. Сергійчук В. Тавруючи визвольний прапор. Діяльність агентури та спецбоївок НКВС-НКДБ під виглядом ОУНУПА. Видання друге, доповнене. К.: ПП Сергійчук М.I., 2006. 184 с.

111. Сергійчук В. Український здвиг: Волинь. 1939-1955 pp. К.: Українська Видавнича Спілка, 2005. 840 с.

112. Сергійчук В. Український здвиг: Закерзоння. 1939-1947 pp. К.: Українська Видавнича Спілка, 2004. 836 с.

113. Сергійчук В. Український здвиг: Наддніпрянщина. 1941-1955 рр. К.: Українська Видавнича Спілка, 2005. 836 с.

114. Сергійчук В. Український здвиг: Поділля. 1939-1955 рр. К.: Українська Видавнича Спілка, 2005. 840 с. 
115. Сергійчук

В. Український

здвиг:

Прикарпаття. 1939-1955 рр. К.: Українська Видавнича Спілка, 2005. 840 с.

116. УГВР в світлі постанов Великого Збору та інших документів 3 діяльности 1944-1951 pp. [Б.м.]: Видання Закордонних частин ОУН, 1956.356 с. (Серія "Бібліотека українського підпільника" Ч. 3)

117. Украинские националистические организации в годы Второй мировой войны. Документи: в 2 т. / [под ред. А. Н. Артизова]. М.: Российская политическая энциклопедия (РОССПЭН), 2012. Т. 1: 1939-1943. $878 \mathrm{c.}$

118. Украинские националистические организации в годы Второй мировой войны. Документи: в 2 т. / [под ред. А. Н. Артизова]. М.: Российская политическая энциклопедия (РОССПЭН), 2012. Т. 2: 1944-1945. 1167 с.

119. Український національно-визвольний рух на Прикарпатті в XX столітті. Документи i матеріали / [відп. ред. проф. Микола Кугутяк]. Т. 2. Івано-Франківськ: КПФ “ЛІК”, 2009. Кн. 1: 1939-1945. $600 \mathrm{c}$.

120. Український національно-визвольний рух на Прикарпатті в XX столітті. Документи і матеріали / [відп. ред. проф. Микола Кугутяк]. Т. 2. Івано-Франківськ: КПФ “ЛІК”, 2010. Кн. 2: 1945-1946. $696 \mathrm{c}$.

121. Український національно-визвольний рух на Прикарпатті в XX столітті. Документи i матеріали / [відп. ред. проф. Микола Кугутяк]. Т. 2. Івано-Франківськ: КПФ “ЛІК”, 2011. Кн. 3: 1947-1957. $768 \mathrm{c}$.

122. УПА в світлі документів 3 боротьби за Українську Самостійну Соборну Державу 1942-1950 pp. [Б.м.]: Видання Закордонних частин ОУН, 1957. Ч. 1. 452 с. (Серія “Бібліотека українського підпільника" Ч. 6)

123. УПА в світлі документів 3 боротьби за Українську Самостійну Соборну Державу 1942-1950 рр. Бойові дії УПА за 1943-1950 pр. [Б.м.]: Видання Закордонних частин ОУН, 1960. Ч. 2. 444 с. (Серія "Бібліотека українського підпільника" Ч. 7)

124. Федорівський С. Нотатки повстанця. Нью-Йорк: Прометей, 1962. $207 \mathrm{c}$.

125. Центральний державний архів вищих органів влади та управління України (далі - ЦДАВО України). Ф. 3833. Оп. 1. Спр. 226.

126. ЦДАВО України. Ф. 3836. Оп. 1. Спр. 67.

127. ЦДАВО України. Ф. 3836. Оп. 1. Спр. 70. 
128. ЦДАВО України. Ф. 3838. Оп. 1. Спр. 4а.

129. ЦДАГО України. Ф. 1. Оп. 23. Спр. 2968.

130. Шлях горіння: Спогади ветеранів ОУН і УПА про національно-визвольну боротьбу в 1940-1950-х pp./ [упоряд. Микола Галів, Василь Ільницький]. Дрогобич: Посвіт, 2008. 520 с.

\section{Information about the author:} Inytskyi V. I.

Doctor of Historical Sciences, Associate Professor, Head of the Department of Ukraine's History, Ivan Franko Drohobych State Pedagogical University 46, Lesya Ukrainka str., Drohobych, Lviv region., 82100, Ukraine 